\title{
Aggregate savings, finance and investment
}

\author{
Fernando J. Cardim de Carvalho*
}

\begin{abstract}
Among the areas in which the Keynesian revolution has been more unsuccessful in changing orthodox views, the relationship between savings and investment must certainly be the best known. Even today, after more than seventy years of publication of The General Theory, policy-makers are still advised to raise national savings rates in order to accelerate growth (and, more recently, end the crisis initiated in 2007 in the United States). Keynes's proposition that investment creates savings, and not the converse, seems to violate fundamental intuitions of economists as well as of the general public. In fact, investment creates savings in monetary economies, the operation of which is harder to grasp than the corn economy that inspires the opposite causality. How is the relationship between savings and investment defined in Keynesian and orthodox theories? In this paper, Keynes's views are contrasted to Wicksell's and to Wicksellian approaches embodied in loanable funds theories. In particular, one searches to clarify the theoretical relationship between the concept of aggregate savings (non-consumed output) and financial savings (net demand for assets) that should be more relevant to a discussion of investment finance. The special concept of finance employed by Keynes is used to stress the role played by banks in Keynes's theory and, in combination with his rejection of Say's law, to clarify the meaning of the sinvestment creates saving " proposition.

JEL classifications: E02, E2I, E44

Keywords: Keynes, Post Keynesian economics, saving and investment
\end{abstract}

* Institute of Economics, Federal University of Rio de Janeiro.

Correspondence Address:

Fernando J. Cardim de Carvalho, Institute of Economics, Federal University of Rio de Janeiro, Av. Pasteur, n. 250, Praia Vermelha, CEP: 22290-240, Rio de Janeiro, Brasil, e-mail: fjccarvalho@uol.com.br.

Received 6 December 20II, accepted 27 February 2012

(C) INTERVENTION 9 (2), 20I2, I97-213 


\section{Introduction}

It has long been argued that some (or perhaps all) of the central ideas advanced by Keynes in The General Theory of Employment, Interest and Money (hereafter GT) have been either ignored or misunderstood by most of his interpreters. In the two or three decades after the Second World War most economists considered themselves to be Keynesian. Keynesianism, however, consisted in fact of propositions that were formulated by other economists, frequently in disregard of Keynes's own views. It was widely accepted that Modigliani's rigid wages assumption explained the non-neutrality of money, that Hicks was right in stating that liquidity preference and loanable funds theories of the interest rate were complementary rather than alternatives, that marginal efficiency of capital (actually corrected to marginal efficiency of investment) was just a fancy name for the old marginal productivity of capital and that the validity of Keynes's emphasis on demand was strictly confined to the short period. Buried in oblivion were the relation between money and uncertainty, Keynes's theory of asset pricing and capital accumulation in $G T$, chapter $\mathrm{I} 7$, the role of expectations and defensive behaviors in causing deficiencies of effective demand and involuntary unemployment, and other ideas that apparently never got a public hearing since few people actually read $G T$ and even less read Keynes's clarifications in the debates that followed its publication. No argument from GT probably suffered a worse fate, however, than the proposed relationship between savings and investment. Even many of Keynes's supporters didn't seem to understand what, after all, Keynes meant by the statement that they are always equal. Some interpreters decided to ignore Keynes's insistence that they have to be equal in value at any moment and postulated that investment and savings were equal only in equilibrium. This view usually was completed by the notion that the income multiplier was the mechanism through which the equality was to be achieved. Others stated that investment and savings are equal ex definitione or, which is a variation of the same idea, that national accounting principles guarantee that they be equal (with changes in inventories being the adjusting variable). Finally, a variation eclectically combining both the preceding arguments seems to argue that ex post, but not ex ante, investment and savings are always equal. Most of the macroeconomic theories presented as Keynesian incorporated one of these interpretations even though Keynes himself explicitly disavowed each and all of them.

The obscurity of the relationship between investment and saving made life easier for those economists intending to restore the "classical« approach, as Keynes called it. If even Keynes's own followers could not agree on what that relationship meant after all, why not go back to the familiar view that had been held for so long? In contrast, the strength of the classical argument is certainly due to its intuitive character. The classical question is: how can anyone accumulate capital without putting aside some fraction of one's income to be accumulated? The answer, of course, and Keynes stressed it more than once, is rone cannotr. The point is not that investment can be realized without savings also being created, but how do the two variables interact in the capital accumulation process. The classical view is that the act of saving has to happen before the act of investment, and is, to some extent, independent of the latter. The divergence between Keynes and the classics relates to the process by which both investment and savings emerge. 
What follows, therefore, will focus on the process of investment in the "classical « and in Keynes's approach. In the next section, we will examine the classical view, taking Wicksell and his followers as its representative authors. Section three will then turn to Keynes's conception of how the investment process works in entrepreneurial (or monetary) economies. Section four will stress the contrasts between the two approaches. Section five concludes.

\section{The "Classical" view of the investment process}

The classical ${ }^{1}$ approach to capital accumulation relies on the very simple and accessible (and, precisely for this reason, very attractive) theoretical concept of a corn economy, an economy where corn is the sole input and output. The concept abstracts from practically every complication one could think of that could be involved in the process of capital accumulation. One conceives an economy which is able not only to provide for its own necessary consumption (i.e. the consumption level which allows the simple reproduction of the community) but can actually produce a net output ${ }^{2}$ that is higher than what is needed for immediate survival. This society can choose between expanding its consumption levels or putting aside some fraction of its consumable output to increase production levels in the future, obtaining an even larger output. In the corn economy we can describe the choice between consumption and saving for investment without any concern either with the behavior of relative prices (there is only one good, corn, that can be consumed or saved and reinvested in expanding production) or of monetary variables (such as, for instance, money prices of inputs and outputs).

In a corn economy, investment cannot be done unless saving takes place previously. Members of this economy have to decide to abstain from consumption before they can use the surplus grain to increase the scale of production. Investment cannot be realized without the previous provision of savings, represented by the non-consumed share of the grain output.

The consideration of a monetary economy should not change the essential picture given by a corn economy in relation to investment and saving. The idea still prevails that one cannot invest without previously saving some fraction of current income although money (or, more exactly, credit) covers the process with a veil. Classical theory along Wicksellian lines aims precisely at piercing this veil.

I We use the term classical in this paper in the same sense Keynes introduced it in GT. Nowadays, this usage is widely considered inadequate, since the view prevails that it should be used only in reference to Classical Political Economy. The expression neo-classical would be preferred by some, but it could be argued that it covers a much larger group of theoretical approaches to the problems that interested Keynes. Be it as it may, the reader is alerted to the specific meaning of the label in this work. Accordingly, the quote signs will be dropped from this point on.

2 Net of the utilization of corn as an input to reproduce the output of corn at the same level next period. 
How does a monetary economy work? To what extent is it different from a corn economy? The first difference is obvious: in monetary economies people and firms are paid in money, not in goods, and exchange money for the goods and services they demand. Classical authors, however, did not seem to make much of this point. Surely, the introduction of money makes trade more efficient, but money is considered only in its means-of-payment function, with no impact on the operation of the economy beyond short-term distortions derived from monetary illusion, the confusion between money and real prices that were expected to dissipate in time. ${ }^{3}$

Saving and investing do become a little more complicated though. Now, savers do not transfer corn directly, in kind, to investors. Two concomitant processes take place. Savers transfer the purchasing power corresponding to the share of their income they do not want to consume to investors in the form of money. The latter then use it to buy the surplus of goods that was left over after consumption expenditures took place. The monetary process is more indirect, but no substantive difference emerges with respect to a corn economy. When savers transfer to investors the money value of their non-spent income, investors are taking hold of precisely the value of non-consumed output.

Acknowledging the monetary form of savings created some difficulties. Real saving has always been taken to be an unambiguous reference to the non-consumed share of income. But when Wicksell dealt with monetary savings he seemed to confuse non-consumed monetary income with hoarding cash. After observing that hoarding implies withdrawing cash from circulation, he added that such act could be compensated by somebody else's dishoarding "with no effect on money in circulation and prices" (Wicksell 2007: 8). And he went on:

»From the economic point of view of the individual the saving achieves its purpose, since the person saving will at a future date consume what he now forgoes and which somebody else will then forgo. From the social point of view, the only result will be that some part of the supply of money will habitually be withdrawn from circulation; or, as we prefer to express it, that the velocity of circulation of all existing money will be retarded. Again, if everybody adopted the same procedure at the same time, this result would not be achieved. So long as saving is continued the price of commodities falls, and if everybody saves uniformly, everybody will continue to obtain just as many commodities for their remaining income as if they had not saved and were in fact not compelled to restrict their consumption. But when once the money so accumulated is returned to circulation, the prices of all commodities will rise, and nobody will be able to increase his consumption. Thus saving will not have involved any sacrifice, and the result will prove to be exactly nothing." (idem: $8-9$ )

3 Marx in fact was one of the few economists to realize that even as a mere means of payment money could change the dynamics of a capitalist economy. According to Marx (1978: 502, 515), the use of money as an intermediary of trades opened what he called a "general possibility of a crisis", since the seller of goods for money could retain it instead of spending it, interrupting the "commodity cycle«. However, Marx also argued that while this created the possibility of crises, it should not be taken as an actual explanation of crises. 
The question was not made easier when Wicksell added another difference between barter and monetary economies: the existence of banks. In its simplest functional definition, a bank is an institution that accepts deposits from the public to use them to make loans to borrowers. Banks were conceived thus as financial intermediaries, standing between savers, who could choose the type and volume of deposits they want, and investors, who would borrow from the bank. ${ }^{4}$ Savers and investors were assumed to be the main, if not necessarily the sole, suppliers and demanders of resources to and from the bank.

Of course, deposits are just a specific modality of loans made to banks. As in the case of other types of loans, banks commit to return the value deposited with them under specified conditions. Demand deposits offer full liquidity, being redeemable on demand by depositors. Time deposits establish some minimum investment period and compensate for it by paying higher interest rates. With the resources collected from depositors, banks can buy assets, such as debt contracts from borrowing firms.

Banks further complicated the relationship between saving and investment but again they were not allowed to change its ultimate nature. Bank deposits and loans dealt with the means to purchase the goods that are going to be accumulated. The possibility of accumulation continued to depend on the desire of income earners to save and of investors to invest. The existence of credit institutions could not change that basic reality. One way to do it was to constrain bank activity to fit perfectly the role of intermediaries between savers and investors, so that the value of loans corresponds exactly to the value of savings. This can only be done, however, at a potentially high price. One has to assume, first, that savers deposit in banks all their savings and nothing but their savings. Unless this condition is accepted, total savings and loanable funds will differ in value. The second condition is that credit supply offered by banks is funded entirely by saving deposits.

The first condition is a problem for two reasons. On the one hand, savers may use themselves some fraction of their savings to finance directly their own or other people's investments. Retained profits are the most important source of funds for investment practically everywhere. Credit can only capture the fraction of savings that will be shifted from savers to (different) investors. On the other hand, and more relevant, banks are not only, and perhaps not even mainly, credit providers. In modern monetary economies, banks are providers of payment system services. The public hold transaction deposits in banks as well as idle deposits that could represent some sort of saving. Frequently both types of deposits are maintained in the same accounts. For banks no essential difference exists between transaction deposits and saving deposits, both being recognized as "sources" of loanable funds, which

4 Modern neoclassical economists maintain the view that "Banks collect savings from depositors and lend the funds to firms and households" (Strahan 20IO: II2). Gorton/Winton (2002) defined sbanklike intermediaries as "firms with the following characteristics: I. They borrow from one group of agents and lend to another group of agents. 2. The borrowing and lending groups are large, suggesting diversification on each side of the balance sheet. 3. The claims issued to borrowers and to lender have different state contingent payoffs. The terms ১borrow and /lend ‘ mean that the contracts involved are debt contracts." 
means that banks lend transactional balances as well as "savings « deposits, violating the second condition for equivalence of total savings and the supply of loanable funds.

Ohlin maintained that the savings supply function, that is, "planned « savings, was the ultimate determinant of the supply of credit, and the same happened to planned investments and demand for credit, despite some discrepancies that could blur the equivalence:

"That the relation between the curves referring to savings and investment and those referring to credit is close should be obvious. If a man plans to save, must he not either plan to invest or to lend? Will not, then, the planned supply of credit be equal to the planned savings, if the use of one's own savings for new investment is treated as giving credit to oneself? No, not quite. It is possible to plan to save and to increase the quantity of cash instead of lending. Also one can plan to extend new credits in excess of planned savings, if one is willing to reduce one's own quantity of cash. Besides, one can plan to extend credit instead of reinvesting scapital made free`, i.e. >depreciation money`. Similarly with the planned demand for credit, which may differ from planned new investment owing to a desire to vary the cash held, to cover expected losses or to finance consumption. But this is only one side of the difference. The other one is that one may plan to take credit for the purchase of old assets, i.e. for financial investment. This has nothing to do with the new investment of the industrial sphere, which is related to savings. One may also plan sfinancial disinvestment‘, e.g. through the sale of a house, and plan to use the proceeds to extend new credit, e.g. to the man who buys the house. Thirdly, the banking system may plan to increase or reduce the volume of credit. Evidently, the curves of demand and supply of credit, which are identical with the curves of supply and demand for claims, are quite different from but interrelated with the curves which refer to planned new investment and savings. " 5 (Ohlin 1937: 425)

Others, such as Dennis Robertson seemed to have savings and bank loans as alternatives rather than transformations of one another when he listed the supply of loanable funds as consisting of: I. current savings; 2. "disentanglings «, that is, past savings currently released as depreciation or working capital; 3. net dishoardings; and 4. net bank loans (Robertson I988: 3$){ }^{6}$

Robertson, and, of course, Wicksell himself, moreover, realized that banks not only were not necessarily constrained when supplying credit by the amount of savings deposits the public desired to hold but that they could actually create credit, given the special nature of their liabilities. Robertson (I988: 4I) acknowledged that:

5 Myrdal (1965: 109-II2) tried to describe the relation between saving and credit but ended up with a proposition where any result is possible depending on how ad hoc assumptions are considered as to bank preferences.

6 Demand for loanable funds includes the same items with changed signals. 
»bank-money comes into existence mainly as the result of loans and investments made by the banking system, and that consequently, in most circumstances, the proximate force determining its amount is a series of decisions made by some person or persons situated within the banking system. $\ll^{7}$

Robertson, however, maintained, without explanation, that:

"The real value of a country's bank-money is the same thing as the amount of real savings which the public has put in the past at the disposal of industry through the medium of the banks, and its amount lies in the discretion of the public and not of the banks." (idem: 42)

Wicksell explicitly recognized the potentially disturbing implications of acknowledging the ability of banks to multiply their liabilities. In his approach, possible divergences between savings and credit were a serious threat to macroeconomic equilibrium. ${ }^{8}$

Money and credit, therefore, made trades more efficient but credit caused the money veil to become thicker. To save a fraction of one's income was to subtract from money circulation by acquiring a bank deposit. However, the bank could put the value of the deposit back into monetary circulation by making a loan. Savings were increased but monetary circulation was intact. A Wicksellian puzzle emerged: should prices go down because savings were increased or stand still since monetary circulation remained the same?

Moreover, the operation of banks allowed the supply of bank credit to diverge from the underlying supply of savings, creating the possibility of new types of imbalances in the economy. These imbalances would be manifest in the possibility that natural rate of interest (that made saving and investment equal) could be different from the market rate of interest (the rate determined by supply of and demand for credit). Of course, all these dilemmas could be avoided if the conditions for the equality of aggregate savings and financial savings were respected. For our purposes, this means that the classical approach contained a fundamental normative view of what should be the scorrect role of banks: in order to minimize imbalances in the economy, they should act essentially as mere intermediaries between savers and investors.

7 "The discovery that money deposited on a guarantee to repay on demand could be partially loaned without endangering the liquidity of the institution in question constituted, however, an important advance in banking technique, which in its turn led to the discovery of the credit note. For just as simply as deposits of money were accepted against a certificate of deposit and were then lent out to others, whilst the certificate of deposit might continue to be used by the owner as a medium of payment and be transferred to others, so also such certificates of deposit might be issued against ample security to persons who had not deposited any money in the bank." (Wicksell 2007: 76)

8 Wicksell tried to attenuate this threat, however, by postulating again a different behavior to saving deposits in comparison to demand deposits: »On the other hand, the difference is great between deposits which are based on money saved, and are therefore intended for long date capitalization, and those deposits which consist of occasional surpluses of bank credits" (Wicksell 2007: 86). He seemed to imply that banks would be more parsimonious in supplying credit on the basis of savings deposits than of demand deposits. 


\section{Keynes on saving and investment}

In A Treatise on Money, published in 1930, Keynes presented his personal version of Wicksell's theory of the interest rate, based on definitions of saving and investment that sharply contrasted with the definitions later proposed in GT. In the Treatise, as he had done before, in his Tract on Monetary Reform, Keynes did not question the fundamental truth of the classical theory. The argument relied on the interplay of two independent functions, saving and investment, meant to represent planned saving and planned investment. In fact, Keynes argued that this was the only definition that made sense, since otherwise they would always be equal in value:

"My definition of income is thought paradoxical because I exclude from it [...] windfall profits and losses, and my definition of saving, being the excess of income thus defined over expenditure on consumption, corresponds to my definition of income. But those who object to these definitions have not, I think, followed out to the end the consequences of rejecting them. For if windfall profits and losses are included in income, $[\ldots]$ and saving as the excess of income thus defined over expenditure on consumption, it follows that saving is in all cases exactly equal to the value of current investment. That is to say the total volume of saving ceases to be a factor having any independent existence. Its amount cannot be affected by the voluntary decision of the various recipients of income as to how much of their income they will spend on consumption; and it solely depends on what the value of current investment happens to be." (CWJMK V: xxiii)

Naturally, a forward-looking concept of planned saving could only relate to expected income. But what if expected income turned itself to be different from realized income? How would actual saving behave? To deal with this problem, Keynes suggested that these unexpected changes in income should be treated separately, as windfall gains or losses, since, being unexpected, they could not have influenced decisions made in the past.

Keynes seemed unsure, however, of what role, if any, should be given to these unexpected, ex post, gains and losses. Keynes's choice, expressed in the famous widow's cruse argument, was the target of heavy criticism because it failed to respect the most obvious point of contrast between planned savings and windfall gain, that is, their asynchrony. Keynes decided to abandon any concept of saving that could depend on the notion of expected income (and actually used this very difficulty against Ohlin in the 1937 debates).

In the interval between the publication of the Treatise and the publication of $G T$, Keynes's views on how a modern entrepreneurial economy works underwent a profound change. The most important change happened not so much with respect to individual concepts and instruments, but at the more abstract level of how a modern monetary economy works. In this new setting, the relationship between investment and saving changed dramatically with respect to the corn economy assumed by the classical view, even in its more modern Wicksellian embodiments. 
To describe it shortly, in a monetary economy, a person planning an investment has two concerns. First, it is necessary to get hold of money to buy the goods that constitute the investment. This is a demand for money, no different in character from the transactional demand for money. Keynes called it the finance motive to demand money. The language used by Keynes in his debate with Ohlin, however, was not particularly fortunate. In fact, it was very equivocal until the very end of their exchange, when Keynes finally made his meaning clear. The finance motive to demand money was initially introduced by Keynes through an analogy with saving that was at a minimum exceedingly ambiguous:

„Planned investment - i.e. investment ex-ante - may have to secure its ,financial provision before the investment takes place; that is to say, before the corresponding saving has taken place. It is, so to speak, as though a particular piece of saving had to be earmarked against a particular piece of investment before either has occurred, before it is known who is going to do the particular piece of saving, and by someone who is not going to do the saving himself. There has, therefore, to be a technique to bridge this gap between the time when the decision to invest is taken and the time when the correlative investment and saving actually occur." (CWJMK XIV: 246)

Only much later, Keynes clarified his point:

"The rate of interest is determined by the total demand and total supply of cash or liquid resources. The total demand falls into two parts: the inactive demand due to the state of confidence and expectation on the part of the owners of wealth, and the active demand due to the level of activity established by the decisions of the entrepreneurs. The active demand in its turn falls into two parts: the demand due to the time lag between the inception and the execution of the entrepreneurs' decisions, and the part due to the time lags between the receipt and the disposal of income by the public and also between the receipt by entrepreneurs of their sale proceeds and the payment by them of wages, etc. An increase in activity raises the demand for cash, first of all to provide for the first of these time lags in circulation, and then to provide for the second of them. Thereafter the demand for cash falls away unless the completed activity is being succeeded by a new activity. A given stock of cash provides a revolving fund for a steady flow of activity; but an increased rate of flow needs an increased stock to keep the channels filled. When decisions are made which will lead to an increase in activity, the effect is first felt in the demand for more cash or ifinance،." (CWJMK XIV: 230, author's emphases)

The finance motive to demand money may be satisfied by a number of sources: retained profits accumulated as bank deposits, bank loans and overdrafts, placement of securities, etc, because there could be some idle liquidity in many points of monetary circulation. But Keynes insisted it is money, not saving that is the object of demand.

The entrepreneur's second concern relates the funding for this investment, that is, the issuance of permanent obligations corresponding to the newly-acquired assets (Keynes 1937b: 40). Although Keynes dedicated very little space to this during the debate with Ohlin, he did develop the idea later, when discussing the ideal timing for placement of public debt 
securities. ${ }^{9}$ Discretionary spending (government expenditures as much as private investment expenditures) creates income, through the multiplier effect. Rising incomes generate rising savings in search for wealth accumulation vehicles. Funding of deficit spending should be timed to coincide with the full operation of the multiplier. Thus, the lag between making the expenditure and the placement of long-term securities

"must also be long enough in point of time for the new savings to reach the ultimate holder, who alone is in a position to embark them in a permanent investment, and to allow him to make an unhurried decision.« (CWJMK XXI: 543)

There still remained the problem of how the ultimate holder's demand for assets will be divided among the several classes of assets, which depends on the public's liquidity preferences. In Keynes's approach, shaping the supply of assets according to the liquidity preferences of buyers is one of the main functions of the financial system.

There are, therefore, three dimensions to the investment process. First, there is a monetary dimension. Investing means acquiring goods of a special nature, and, as it is the case of any act of spending, the buyer of investment goods needs to get hold of money to do it. This is what Keynes called "finance ${ }^{\text {Io }}$ It is a problem of monetary circulation, that is, whether there is sufficient liquidity in the economy to allow discretionary expenditures to take place without pushing the interest rate upwards. ${ }^{\text {II }}$

9 One may see Hyman Minsky's work as dealing mainly with how economic agents fund their asset accumulation.

IO The peculiar sense in which Keynes used the term finance gave rise to some confusion not only in his own debates with contemporaries but also among later generations of Keynesian economists and their opponents, particularly those defending loanable funds theories. Keynes clarified the meaning he attributed to the term finance in his final contribution to the debate with Ohlin, Robertson and Hawtrey on the relationship between saving and investment: "A large part of the outstanding confusion is due, I think, to Mr. Robertson's thinking of ,financer as consisting in bank loans; whereas in the article under discussion I introduced this term to mean the cash temporarily held by entrepreneurs to provide against the outgoings in respect of an impending new activity (CWJMK XIV: 229). Kalecki, usually less concerned with the niceties of the Classical approach, makes investors go directly to the central bank to obtain finance (Kalecki 197I).

II How liquidity is supplied and under what constraints is not explored in GT. In fact, an enduring debating issue among post Keynesians has been why all discussion about banks and the degree of endogeneity of the money supply, present in the Treatise on Money, was not included in GT. One possible reason is given by Keynes in the preface to $G T$, when he states that »[t]his book [...] has evolved into what is primarily a study of the forces which determine changes in the scale of output and employment as a whole; and, whilst it is found that money enters into the economic scheme in an essential and peculiar manner, technical monetary detail falls into the background " (Keynes 2007: xvi). In the Treatise, creation of bank money, which Keynes identified as the source of endogeneity of the supply of means of payment, was examined in volume II, the "applied « theory of money, which may explain the reference to »technical detail« given in the preface to GT. The relation between the Treatise and GT, as well as later contributions, such as Minsky's, in this area was examined in Cardim de Carvalho (1999). 
Secondly, there is the goods market dimension. For an investment to be realized it is necessary that non-consumable output is made available. To save is actually to release goods, labor and means of production to be used as investment. ${ }^{\mathrm{I2}}$ Keynes argued insistently that there can be no investment without the concomitant generation of savings.

Saving though is created at the same time that investment takes place, not before, because investment is the value of expenditure in excess of consumption expenditures, while the goods and services that are made available for this investment are the output in excess of the goods purchased for consumption purposes. This is why investment and saving are always equal, not because they are two different names for the same thing or because this is a result of some definitional trick or accounting practice. ${ }^{13}$ The difference with the classics is, first, the sequence through which the investment process develops, beginning in the money market so that the investment expenditure can be made, which causes the corresponding saving to come into existence as investment goods are produced to satisfy the demand; second, the acknowledgment that saving can be increased either by reducing expenditures (when the economy is in full employment) or by increasing income (when there is involuntary unemployment). ${ }^{\mathrm{I}}{ }^{\mathrm{O}}$ Of course, this second alternative did not exist in the Classical world of Say's law.

There is finally a third dimension, the financial dimension. To save is not only to release goods, labor and means of production but it is also to demand assets. As Keynes (2007: I66) stated it, once a person decides how much of his or her income will be spent on consumption (and therefore how much will be saved), he or she still has to decide in which form the saving will be stored, choosing among the available classes of assets. The saver may be able, for instance, to keep non-consumed income in the form of liquid assets, buying liquid financial assets issued by banking institutions, or less liquid assets, sold by other financial or nonfinancial institutions. Savers, therefore, will make their wealth accumulation decisions in

I2 "For the object of saving is to release labour for employment on producing capital-goods such as houses, factories, roads, machines, and the like. But if there is a large unemployed surplus already available for such purposes, then the effect of saving is merely to add to this surplus and therefore to increase the number of the unemployed." (Keynes 1963: 151)

I3 "The equivalence between the quantity of saving and the quantity of investment emerges from the bilateral character of the transactions between the producer on the one hand and, on the other hand, the consumer or the purchaser of capital equipment " (Keynes 2007: 63). "But no one can save without acquiring an asset, whether it be cash or a debt of capital-goods; and no one can acquire an asset which he did not previously possess, unless either an asset of equal value is newly produced or someone else parts with an asset of that value which he previously had." (idem: 8I-82)

I4 "The reconciliation of the identity between saving and investment with the apparent ifree-wilk of the individual to save what he chooses irrespective of what he or others may be investing, essentially, depends on saving being, like spending, a two-sided affair. [...] Every such attempt to save more by reducing consumption will so affect incomes that the attempt necessarily defeats itself. It is, of course, just as impossible for the community as a whole to save less than the amount of current investment, since the attempt to do so will necessarily raise incomes to a level at which the sums which individuals choose to save add up to a figure exactly equal to the amount of investment." (Keynes 2007: 84) 
accordance with their liquidity preferences, choosing among assets made available by banks and financial and non-financial entities.

Thus, the investment process in a monetary or entrepreneurial economy follows a very different timeline than that conceived by Classical approaches. Keynes emphasized that investment expenditures require money, not income or saving. ${ }^{\text {Is }}$ Banks, however, are also important to Ohlin's Stockholm School narrative. At the end of the day, the real points of contention between Keynes and Wicksellians are three: first, whether banks are supplying money (by creating deposits) or credit (by extending loans); secondly, if the input banks need to do their job is monetary reserves or ex-ante (or desired) savings; and third, whether income (and saving) is fixed or variable. Keynes answered that banks supply money by creating deposits on the basis of a given level of reserves. In addition, total income was determined by expenditure. Ohlin's answer is that banks supply credit fed by the deposits originating in desired savings. His view on income determination was not entirely clear, but Wicksell's was: expenditure determines nominal income, but cannot affect real income.

\section{Contrasts between Keynes's and Classical Wicksellian approaches}

At a fundamental level, the main bone of contention between Keynes's and Wicksell's theoretical approaches resides in their different concepts of a monetary economy. While Wicksell seemed to have considered a monetary economy a modified form of a barter economy, Keynes considered monetary economies to be an entirely different social arrangement, where production and capital accumulation is pursued by firms motivated by the expectation of money profits.

Keynes considered firms to be much more than mere groupings of consumers trying to exploit some possible increasing returns from collective production. As Keynes put it:

"An entrepreneur is interested, not in the amount of product, but in the amount of money which will fall to his share. He will increase his output if by so doing he expects to increase his money profit, even though this profit represents a smaller quantity of product than before. The explanation for this is evident. The employment of factors of production to increase output involves the entrepreneur in the disbursement, not of product, but of money.«(CWJMK XXIX: 82, Keynes's emphasis ${ }^{16}$

I5 "the transition from a lower to a higher scale of activity involves an increased demand for liquid resources which cannot be met without a rise in the rate of interest, unless the banks are ready to lend more cash or the rest of the public to release more-cash at the existing rate of interest. If there is no change in the liquidity position, the public can save ex-ante and ex-post and ex-anything-else until they are blue in the face, without alleviating the problem in the least-unless, indeed, the result of their efforts is to lower the scale of activity to what it was before." (Keynes 1937: 668)

I6 To be fair, Wicksell (2007: 6) did warn against taking his view too far: »Naturally, however, our simplification is only provisional. Economists frequently go too far when they assume that the economic laws which they have deduced on barter assumptions may be applied without qualification to actual 
Firms aim at accumulating wealth under monetary form because money is wealth in generic form, as Marx (1977: 233) once wrote. In fact, not only firms, but individuals too are supposed to prefer to accumulate wealth in monetary form. ${ }^{17}$ In these economies, the prime consideration for everybody is liquidity.

As explained by Paul Davidson (2002: 7), »in Keynes's scheme of things, real world financial markets provide liquidity and not necessarily efficiency«, while for »the classical scheme, free financial markets are the efficient allocator of capital goods that promotes the economic progress of society." Liquidity is provided in two ways: I. banks create liquidity, by creating deposits to buy assets from the public, for instance, when a loan is conceded to firms or individuals, by means of deposit creation, because banks' deposit liabilities are generally accepted as means of payment; 2. non-banking financial institutions intermediate liquidity by finding in the economy liquidity-holders willing to trade liquid for non-liquid assets in exchange for a reward, the interest rate (Cardim de Carvalho/Kregel 20IO).

The ability of banks to create finance radically separates Keynes and the Classics. "Keynesian" banks can create finance because their liabilities are accepted as means of payment. They are not bound by whatever value depositors wanted to lend to them previously. ${ }^{18}$ They actually create deposits as they lend, in a purely bookkeeping operation. The only constraints on the decisions of banks to lend, that is, to issue deposit liabilities to the credit of borrowers, are the availability of reserves and their own liquidity preferences.

Banks in the Classical world, in contrast, do not create funds, they can only intermediate resources given up by savers. As stated in Gurley and Shaw (I955) paradigmatic presentation, financial institutions capture financial resources from surplus units (those who plan to spend less than their current income) and transfer them to deficit units (those planning to spend more than their current income). Banks are, thus, no different from other intermediaries:

"We take exception to the view that banks stand apart in their ability to create loanable funds out of hand, while other intermediaries in contrast are busy with the modest brokerage function of transmitting loanable funds that are somehow generated elsewhere. Neither banks nor other intermediaries create loanable funds. That is the prerogative of spending units with surpluses on income and product account." (Gurley/Shaw I955: 52I)

conditions, in which money actually affects practically all exchanges and investments or transfers of capital.« Keynes, on the other hand, was more affirmative: "The idea that it is comparatively easy to adapt the hypothetical conclusions of a real-wage [barter] economics to the real world of monetary economics is a mistake." (CWJMK XIII: 4IO)

I7 "Because, partly on reasonable and partly on instinctive grounds, our desire to hold money as a store of wealth is a barometer of the degree of our distrust of our own calculations and conventions concerning the future. [...] The possession of actual money lulls our disquietude; and the premium which we require to make us part with money is the measure of our disquietude." (CWJMKXIX: II6) I8 See the exchange between Keynes, McKenna and Brand during a session of the MacMillan Committee, (CWJMK XX: 87-89). A detailed theoretical and historical account of banks from this point of view is offered by Kregel (1998). 
Wicksell, on the other hand, does recognize that banks can multiply credit, but this is not an element of the normal dynamics of market economies. If banks do extend credit beyond the value of desired savings, inflation will ensue because banks can extend credit but cannot guarantee the availability of goods and services to attend the increased demand. In equilibrium, banks should be neutral, that is, the market rate of interest should be equal to the natural rate of interest. It is interesting to notice that the divergence between the two rates, and the possibility of cumulative disequilibria emerging from the operation of banks, which interested Wicksell very much, is not even mentioned by Ohlin in his summary of the Stockholm School arguments. The apparent contradiction between Gurley and Shaw and Wicksell dissolves when one realizes that they are in fact saying exactly the same thing: that financial systems can create credit, but not loanable funds, because loanable funds are the value of people's desired savings not of actual loans. As Gurley and Shaw added, banks and nonbanks "are loanable-funds brokers. Both create credit" (idem: 522).

Keynes's opposition to the Classical approach was thus wholesale. The narrative of the investment/saving link in each theory was based on a dramatically different view of how the economy is structured and operates. In particular, the roles played by money and finance in each approach simply cannot be reconciled.

Keynes also added some criticisms of specific topics in the Stockholm approach, as described by Ohlin. In particular, Keynes took exception of the concept of ex-ante or planned savings. ${ }^{19}$ According to Keynes such a variable is not observable and do not result in any observable behavior. One cannot demand assets with ex-ante savings, one cannot deposit desired savings. In Keynes's words, »the ex-ante saver has no cash, but it is cash which the ex-ante investor requires" (Keynes 1937: 665-666).

Moreover, Ohlin's banks seem to receive only savings deposits, while Keynes's bank receives both transaction deposits and savings deposits. In other words, Keynes acknowledges that the public does not maintain as deposits only the value which they don't intend to spend, but in fact most of the purchasing power they want to keep in liquid form. Therefore, the bank does not lend only desired savings, but all resources it can put its hands on. ${ }^{20}$

The central point, therefore, is that what matters for investment is neither realized savings nor, in fact, ex ante or desired savings. Banks, not savers, are the suppliers of the liquidity that the investor needs to order investment goods. The classical bank depends on savers to make deposits. The Keynesian bank creates deposits when they buy assets. The funds are spent generating income out of which the necessary saving is realized. Wicksell, as we saw, recognized that banks may multiply deposits but saw it as a fundamentally destructive possibility enhancing the possibility that self-amplifying disequilibria would emerge. Keynes knew that such disequilibria might emerge, but only when full employment prevails. 


\section{Conclusion}

The persistence of Classical ideas on the relation between saving and investment so many decades after the publication of the GT bears witness to the power of their appeal not only for the general public but even to economists, who perhaps should know better. In fact, that so many economists still think that saving is a pre-condition to investment, just as it was in the corn economy, bears witness also to the difficulty of understanding how modern economies work. Of course, the persistence of the corn economy model of thought is also responsible for the correlated ideas that an economy, like a family, has to live within its means and that austerity is the right recipe to deal with a debt overhang.

Keynes's proposition that investment creates saving sounds to many people the same as saying that capital can be created out of nothing. Keynes fought this notion, and even wrote in $G T$ that he considered the notion entertained by Classical economists according to which no investment can be realized without savings a lesser mistake (Keynes 2007: 83). Capitalism does no magic. Keynes's point is that modern economies work according to a different logic, subject to different constraints, with agents moved by different stimuli in comparison to a corn economy. These economies seldom operate at full employment, and because of that investments may not need a previous decision to save to release real resources from consumption. Investment and consumption actually move together in these economies (except at full employment). This was the point of creating the concept of a monetary economy.

The contrast between Keynes and the Classics on the matter of investment and saving, therefore, is not a question of defining the terms differently but of fitting them in different narratives. In Keynes's monetary economy, when a decision to invest is made, the investor has to get hold of money to buy the desired investment goods. It is in the money circulation that this demand is accommodated, through the satisfaction of what he called the finance motive to demand money. Once the investor is in possession of the necessary amount of money he orders those goods. The producer of investment goods set in motion the process of production in which those goods will come into existence, and the corresponding income will be appropriated by the factors of production. At this moment, investment is no longer a plan, but a reality and, at the same time, saving, in the form of non-consumable output, comes into existence too. Factors of production will then use some fraction of their higher income to increase their own consumption raising output and income again and again, until this multiplier process is exhausted. At this point, there will be a demand for assets, i.e. desired savings, that is of the same value as the original investment.

From this point of view, criticizing the Classical view and its implications in terms of economic policy cannot circumvent the need to substitute the narrative of a monetary economy for the intuitive corn economy model that dominates economic thought. As suggested in the paper, crucial steps to be emphasized in the new narrative is the assumption that in monetary economies output levels (and employment) are decided on the basis of the expectations of demand of businessmen and that banks are capable of creating the liquidity that can satisfy the demand for money that initiates the process. This is the obvious starting 
point of Keynesian criticisms of the macroeconomic policies currently pursued in the United States and in the European Union. Decreasing incomes cannot generate increasing savings. Savings releases resources, but releasing resources when there is already a large volume of idle labor and means of production is a waste pure and simple. To expect that increasing waste and decreasing income will increase lenders' confidence is to mistake religious faith for the analysis of businessmen's motives. As illustrated by the quantitative easing policies implemented by the European Central Bank in late 20II, supplying liquidity increases confidence, not imposing draconian economy measures as it was demanded from many European countries.

In sum, finance, from a Keynesian perspective, is therefore a far more complex function than merely intermediating saving or capital. Finance creates and distributes liquidity. Investment, like consumption, relies on the possibility of paying for the desired goods, so an appropriate rendition of how investment comes into existence requires a proper understanding (including measurement) of how finance is created and allocated. Investment financing will be related, of course, to aggregate saving, since investment and saving are equal. Before examining if investment financing is being adequately provided, however, it is essential that a proper knowledge of how the financial (including the banking) system is structured and how the segments relate to each other is obtained.

\section{References}

CWJMK (197I-I982): The Collected Writings of John Maynard Keynes, edited by D. Moggridge and E. Johnson, London: MacMillan and Cambridge: Cambridge University Press for the Royal Economic Society. Volumes are identified as CWJMK, followed by volume number in Roman Numerals.

Cardim de Carvalho, F. (I999): On banks' liquidity preference, in: Davidson, P., Kregel, J. (eds.), Full Employment and Price Stability in a Global Economy, Cheltenham: Edward Elgar.

Cardim de Carvalho, F., Kregel, J. (20I0): What do Financial Systems and Financial Regulators do?, Rio de Janeiro: Ibase.

Davidson, P. (2002): Financial Markets, Money and the Real World, Cheltenham: Edward Elgar. Gorton, G., Winton, A. (2002): Financial intermediation, NBER Working Paper Nr. 8928.

Gurley, J., Shaw, E. (1955): Financial aspects of economic development, in: The American Economic Review, 45(4), 515-538.

Kalecki, M. (1971): Selected Essays on the Dynamics of the Capitalist Economy, Cambridge: Cambridge University Press.

Keynes, J.M. (1937): The ex ante theory of interest rates, in: The Economic Journal, 47(188), $663-669$.

Keynes, J.M. (1963): Essays in Persuasion, New York: W.W. Norton.

Keynes, J.M. (2007): The General Theory of Employment, Interest and Money, London: Palgrave/ MacMillan.

Kregel, J. (1998): The past and future of banks, Quaderni di Ricerche, 2I, Roma: Bancaria Editrice. Marx, K. (1977): Grundrisse, Harmondsworth: Penguin/New Left Review. 
Marx, K. (1978): Theories of Surplus Value, Vol. II, Moscow: Progress Publishers.

Myrdal, G. (1965): Monetary Equilibrium, New York: Augustus M. Kelley.

Ohlin, B. (1937): Rejoinder, in: The Economic Journal, 47(187), 423-427.

Robertson, D. (1988): Essays in Monetary Theory, Westport: Hyperion Press Inc.

Strahan, P. (2010): Liquidity production in Twenty-first-century banking, in: Berger, A., Molyneux, P., Wilson, J. (eds.), The Oxford Handbook of Banking, Oxford: Oxford University Press.

Wicksell, K. (2007): Lectures on Political Economy, Vol. II Money, Auburn: Ludwig von Mises Institute. 
